\title{
Transcriptomic analysis of shell repair and biomineralization in the blue mussel, Mytilus edulis
}

Tejaswi Yarra ${ }^{1,2}$, Kirti Ramesh ${ }^{3}$, Mark Blaxter ${ }^{4}$, Anne Hüning ${ }^{3}$, Frank Melzner ${ }^{3}$ and Melody S. Clark ${ }^{2 *}$

\begin{abstract}
Background: Biomineralization by molluscs involves regulated deposition of calcium carbonate crystals within a protein framework to produce complex biocomposite structures. Effective biomineralization is a key trait for aquaculture, and animal resilience under future climate change. While many enzymes and structural proteins have been identified from the shell and in mantle tissue, understanding biomieralization is impeded by a lack of fundamental knowledge of the genes and pathways involved. In adult bivalves, shells are secreted by the mantle tissue during growth, maintenance and repair, with the repair process, in particular, amenable to experimental dissection at the transcriptomic level in individual animals.

Results: Gene expression dynamics were explored in the adult blue mussel, Mytilus edulis, during experimentally induced shell repair, using the two valves of each animal as a matched treatment-control pair. Gene expression was assessed using high-resolution RNA-Seq against a de novo assembled database of functionally annotated transcripts. A large number of differentially expressed transcripts were identified in the repair process. Analysis focused on genes encoding proteins and domains identified in shell biology, using a new database of proteins and domains previously implicated in biomineralization in mussels and other molluscs. The genes implicated in repair included many otherwise novel transcripts that encoded proteins with domains found in other shell matrix proteins, as well as genes previously associated with primary shell formation in larvae. Genes with roles in intracellular signalling and maintenance of membrane resting potential were among the loci implicated in the repair process. While haemocytes have been proposed to be actively involved in repair, no evidence was found for this in the $M$. edulis data.

Conclusions: The shell repair experimental model and a newly developed shell protein domain database efficiently identified transcripts involved in M. edulis shell production. In particular, the matched pair analysis allowed factoring out of much of the inherent high level of variability between individual mussels. This snapshot of the damage repair process identified a large number of genes putatively involved in biomineralization from initial signalling, through calcium mobilization to shell construction, providing many novel transcripts for future in-depth functional analyses.
\end{abstract}

Keywords: Mollusc, Bivalve, Shell matrix proteins, Haemocytes, Calcium

\footnotetext{
* Correspondence: mscl@bas.ac.uk

${ }^{2}$ British Antarctic Survey, Natural Environment Research Council, High Cross,

Madingley Road, CB3 OET Cambridge, UK

Full list of author information is available at the end of the article
}

(C) The Author(s). 2021 Open Access This article is licensed under a Creative Commons Attribution 4.0 International License, which permits use, sharing, adaptation, distribution and reproduction in any medium or format, as long as you give appropriate credit to the original author(s) and the source, provide a link to the Creative Commons licence, and indicate if changes were made. The images or other third party material in this article are included in the article's Creative Commons licence, unless indicated otherwise in a credit line to the material. If material is not included in the article's Creative Commons licence and your intended use is not permitted by statutory regulation or exceeds the permitted use, you will need to obtain permission directly from the copyright holder. To view a copy of this licence, visit http://creativecommons.org/licenses/by/4.0/. The Creative Commons Public Domain Dedication waiver (http://creativecommons.org/publicdomain/zero/1.0/) applies to the data made available in this article, unless otherwise stated in a credit line to the data. 


\section{BackgroundK}

The molluscan shell is composed of varying proportions of organic components (largely proteins, acidic polysaccharides and chitin) and the calcium carbonate polymorphs: calcite and aragonite. Combined, these give the shell of each mollusc species their unique physical and chemical properties. During shell formation, calcium carbonate is produced from the reaction of calcium ions with bicarbonate ions, and evidence suggests that the proteins (shell matrix proteins or SMPs) determine the mineral polymorph and are involved with the nucleation, growth and termination of the calcium carbonate crystals [1]. SMPs are secreted by the mantle, a layer of tissue between the shell and the rest of the organs it encloses, into the extrapallial fluid, where they are incorporated into the growing edge of the shell along with the calcium carbonate crystals [1]. Hence, the processes of the production of crystal lattices and proteinaceous extracellular matrix are intimately linked in molluscan biomineralization.

SMPs have been identified and characterized in multiple proteomic studies via the extraction of proteins directly from shells. SMPs have been described from several molluscan genera, which have been collated in an in-house SMP database (https://doi.org/10/cz2w [2]). This database contains protein sequences of both putative and known SMPs identified in Uniprot using keyword searches related to molluscan biomineralization (full details in methods). Complementary to these proteomic data, transcriptomic data have been generated from mantle tissue and putative biomineralization loci identified through sequence similarity to already identified SMPs. Transcriptome data have also been deployed to propose source proteins for proteomic mass spectrometry data [3]. The specific roles of SMPs in biomineralization have been explored through functional experimentation. For example, RNA interference mediated knock-down of Pif and PfN23 genes in the mantle disrupted nacre formation in Pinctada imbricata fucata $[4,5]$, while knockdown of the Shematrin gene resulted in disordered foliate structures in Chlamys farreri [6]. In vitro studies on the effects of SMPs on calcium carbonate crystal formation revealed functional specificity. Pif induced calcium carbonate crystal growth and PfN23 and p10 accelerated crystal growth in $P$. imbricata fucata $[4,5,7]$. In contrast, perlinhibin and perlwapin from Haliotis laevigata, prismalin-14 from P. imbricata fucata and caspartin from Pinna nobilis were found to inhibit crystal growth [4, 8-10]. Although SMPs and mantle transcripts from multiple molluscan species have been identified, there are still many unknowns in the biomineralization process.

Shell matrix proteomics can only identify proteins that are incorporated into the shells and cannot report on enzymic or other upstream processes. Similarly, while mantle transcriptomes have been used to identify putative biomineralization related transcripts, this has largely been based on sequence similarity to previously known SMPs. Importantly, mantle tissue is made up of multiple different cell types with different origins and roles including ectodermal and mesodermal components involved in sensory and muscular functions as well as epidermal and secretory tissue involved in shell formation. This makes it hard to ascertain whether a transcript is involved in biomineralization or in multiple other functions. Species-specific adaptations may also obscure shared biology. For example, it has been proposed that haemocytes, found in the open circulatory system of molluscs, may play an active role during shell formation by carrying amorphous calcium, calcium crystals or SMPs to the site of shell formation [11-13]. However, the involvement of haemocytes in mollusc biomineralization may be species-specific, as they were associated with immune processes in Crastostrea gigas, but with ion regulation and calcium transport in C. virginica [14]. While in vivo and in vitro experiments have identified SMPs as integral to shell production, the molecular players in other shell formation processes such as the uptake, mobilisation and storage of calcium and bicarbonate ions, are unclear [15]. Molluscs are proficient at repairing shell damage [16]. Repair of experimentallyinduced shell damage has been used in several species to explore the dynamics of the repair process and the genes and proteins involved in biomineralization [17-22]. These previous studies used either pooled individuals or separate controls and treated animals. Therefore part of the aim of this study was to validate the matched pair design using individuals via Illumina RNA-Seq.

The blue mussel Mytilus edulis is endemic to European and West Atlantic waters, and is an important species in commercial aquaculture (http://www.fao.org/ fishery/species/2688/en). M. edulis shells are composed of an outermost organic layer of periostracum, a middle layer consisting of calcite based prismatic structures, and an innermost layer of aragonite based laminar structure called nacre [23]. In this study, samples generated as part of a previously published $M$. edulis shell regeneration experiment [20] were used to measure gene expression changes consequent on damage and repair of adult shells using RNA-Seq transcriptomics. Importantly the experimental model, using within-individual controls enabled identification of differences in gene expression patterns due to the systemic effects of injury and the genetic difference between individuals from those associated with the processes occurring at the wound site. Due to financial constraints and the need for a (relatively) high level of replication $(n=5)$ and to sequence four tissues per animal, this study focused on the time point 
with the most distinct and homogenous calcification response. A database of genes, proteins and protein domains previously identified as SMPs or associated with SMPs was generated to explore the involvement of these candidates in the shell repair process through time. In addition, comparisons were carried out against $M$. edulis haemocyte expressed sequence tag (EST) datasets to assess the contribution of haemocytes to shell repair and against transcriptome data from $M$. edulis larvae during the synthesis of the first larval shell to validate novel SMPs.

\section{Results}

\section{Study design}

The tissue samples from five 5 individuals analysed in this study were generated during a longitudinal study of shell repair in adult M. edulis [20]. Recent studies have shown that most Mytilus populations in Europe are hybrids of M. edulis, M. galloprovincialis and M. trossulus, with varying degrees of admixture [24]. Kiel animals are characterized by a high proportion of Mytilus edulis alleles (ca. $80 \%$ ) and admixture of M. trossulus (ca. 20\%) alleles [25] (Stuckas, Melzner et al. unpublished). A Kiel hybrid transcriptome was assembled and sequenced reads were mapped on this hybrid transcriptome. Since we utilized five replicate animals, we expect that our statistical analyses captured at least the essential transcriptomic signatures related to shell repair. Details of the experimental procedures are given in the original publication, but the salient features are reviewed here.
Holes were drilled in the centres of the left valves of a cohort of wild-sampled, live M. edulis, above the central mantle zone (Fig. 1A). The right valves were left undamaged. There were no mortalities during the course of the experiment. All individuals successfully initiated repair of the damaged valve (Fig. 1B). By day 29 post-damage, the holes were covered with an outer (water facing) organic layer covering the damaged shell areas, as well as calcitic layers deposited on these, yet no aragonitic layers, as verified by Scanning Electron Microscopy (SEM) and Raman Spectroscopy in the original study [20]. In addition, a PCR-based expression assessment of mantle tissue showed that a key calcite formation gene, nacrein, was highly expressed [20], hence the 29 day time point was appropriate for studying shell repair and deposition of calcite. The mantle edge and central mantle zones of each valve (control and damaged) were collected from five individuals for assessment of differential gene expression at 29 days post-damage, yielding 20 samples in total. Comparison of gene expression in mantle edge and central mantle, within a valve, and between valves within an individual, enabled the isolation of gene expression changes due to the injury-repair processes in the tissue performing the repair (central mantle of the damaged valve) from general processes active in the valve (comparing central versus edge in both damaged and undamaged valves) and systemic processes induced by the repair process (left and right valves in each individual). These within individual data controlled for the expected, large, inter-individual differences in gene
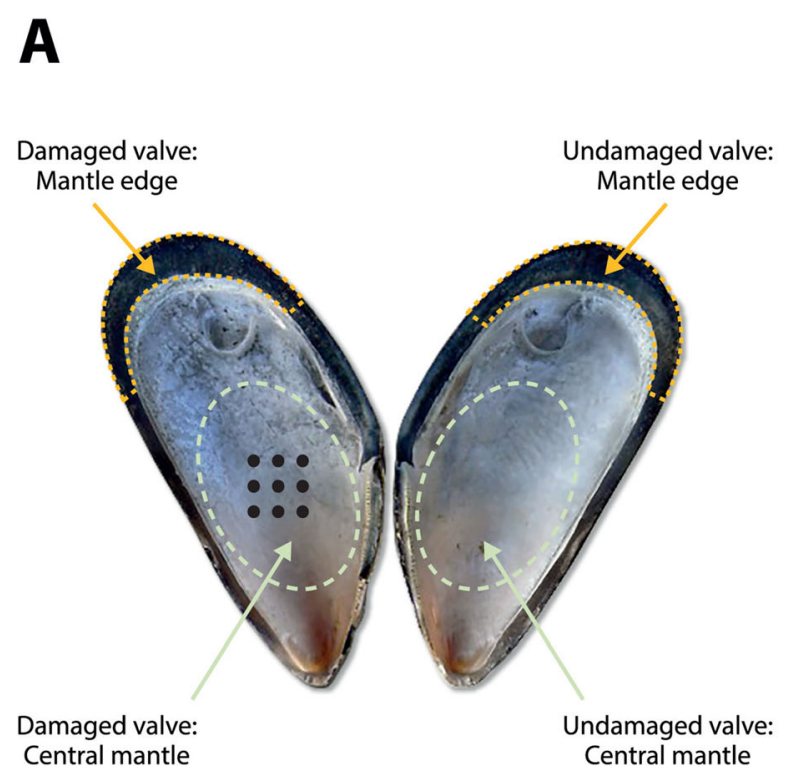

B

\section{B}

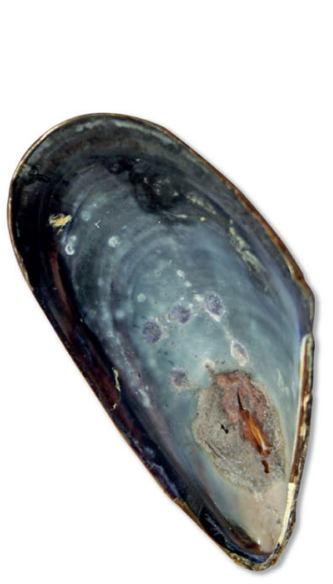

Central mantle

Central mantle

Fig. 1 The paired valve design for assessing shell repair in Mytilus edulis. A Location of drilled holes on the left valve, and the areas of mantle tissue sampled from both valves. B Typical extent of healing 29 days after drilling. Picture attributions (A) Picture obtained and modified under Creative Commons license (2006) from F. Lamiot, Moule, Miesmuscheln, mussel (anatomia and shell), url: https://commons.wikimedia.org/wiki/File: Moules_Miesmuscheln_mussel3.jpg; (B) from Frank Melzner with permission 
expression profiles in Mytilus species, which are all outbreeders and highly heterozygous [26, 27].

\section{Transcriptome assembly, filtering and annotation}

Transcriptomic analysis (Illumina RNA-Seq) generated 714 million raw read pairs in total, with 601 million read pairs remaining after adapter trimming and quality and length filtering. Because of the high genetic variability between M. edulis individuals and haplotypes, and thus poor mapping of reads from individuals in this study to previously generated transcriptomic and genomics data, a de novo transcriptome was assembled to act as reference. The pooled, cleaned read set was down-sampled to 31 million read pairs by in silico normalization. These were assembled using the Trinity pipeline into 560,776 putative genes with 874,699 transcript fragments (likely isoforms). Filtering of the assembly to eliminate expression noise (including putative genes only if they had more than 1 mapped read per million mapped reads in at least $10 \mathrm{li}-$ braries) yielded 30,822 putative genes, with 158,880 transcript fragments (Table 1). These data are similar in magnitude to a recently produced $M$. edulis transcriptome, which also sourced animals from the Baltic [28]. Reads were aligned from each sample to this filtered reference and gene expression was assessed by summing the counts of mapped read pairs per putative gene.

\section{Differential gene expression}

Multidimensional scaling (MDS) plots of the digital expression levels showed separation between mantle edge and central mantle tissues in dimension 1 , with dimension 2 roughly corresponding to different individuals (Fig. 2A). There was a significant difference in expression levels in the central mantle both between damaged and undamaged valves and between individuals (Fig. 2B). Although the expression levels of mantle edge libraries

Table 1 Mantle transcriptome assembly metrics

\begin{tabular}{ll}
\hline Main assembly & \\
Trinity genes & 560,776 \\
Trinity transcripts & 874,699 \\
Filtered assembly (> $\mathbf{C P M}$ in $\geq \mathbf{1 0}$ libraries) & \\
Trinity genes & 30,822 \\
Trinity transcripts & 158,889 \\
Protein sequences (ORF $\geq 100$ amino acids) & 81,456 \\
Filtered assembly features & \\
\% GC & 33.54 \\
N50 (bp) & 1,602 \\
Minimum length (bp) & 201 \\
Maximum length (bp) & 26,467 \\
Total assembled bases (Mbp) & 181 \\
\hline
\end{tabular}

also showed separation between different individuals, there was no significant difference between the damaged and undamaged valves (Fig. 2C). Four pairwise comparisons were made for differential gene expression between the tissues and valves (Table 2; Fig. 3). In both the damaged and undamaged valves, many putative genes were found to be differentially expressed between the mantle edge and the central mantle (Fig. 3A,B). When the mantle of the damaged and undamaged (control) valves were compared, 653 transcripts were highly expressed in the central mantle of the damaged valve during shell repair, with 54 of these transcripts having sequence similarity with SMPs (Fig. 3C, Table 2). No putative genes were identified as differentially expressed between the mantle edge tissues of damaged and control valves (Fig. 3D).

\section{Annotation of transcripts associated with damage-repair}

Further in-depth analysis was restricted to the 653 putative genes associated with the comparison of damaged and control central mantle tissues (Fig. 3C, Table 2), as these were most likely to be involved in damage-repair. All 653 genes were upregulated in the damaged valve undergoing repair. Gene ontology analysis of these 653 genes showed enrichment, compared to the total putative gene translation dataset of several molecular processes associated with protease inhibition (including serine-type endopeptidase inhibition), chitin-binding and metalloendopep tidase activity (Table 3). Sequence similarity searches identified specific transmembrane transporters, proteases and protease inhibitors, signalling molecules and tyrosinases in this gene set (Figs. 4 and 5). Just over $8 \%$ (54 of 653) of these putative genes had sequence similarity with known SMPs or domains associated with SMPs (Fig. 4). In addition to identification of homologues of previously described SMPs, we identified a number of putative genes that had no strong sequence similarity to known SMPs but contained SMP-associated domains such as VWA (chitin-binding), EF-hand, FAMeT, Kazal, and TIMP (Fig. 4).

The initial stages of embryonic shell formation in $M$. edulis are characterised by the deposition of aragonite, while the adult shell has both calcite and aragonite microstructures. However, analyses in other species such as the gastropod Lymnaea stagnalis and the oysters $P$. imbricata fucata and Crassostrea gigas have revealed similarities in gene expression repertoires between adult and larval shells $[29,30]$. Many of the differentially expressed genes with SMP annotations identified in this study were also differentially expressed in the transcriptomics dataset from the prodissoconch I stage of $M$. edulis developing larvae (Fig. 4) [31] (Fig. 4). Furthermore, to identify whether haemocytes could be involved in shell repair processes, 2,194 sequences from a Mytilus 
A

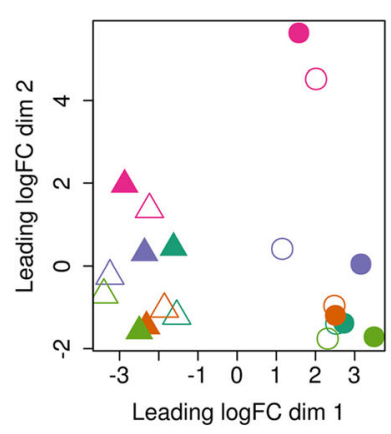

Sample Number:

- 001 - $008=019$

- 002 - 017

Tissue Type:

- Central Mantle - Left/Damaged valve

- Mantle Edge - Left/Damaged valve
B

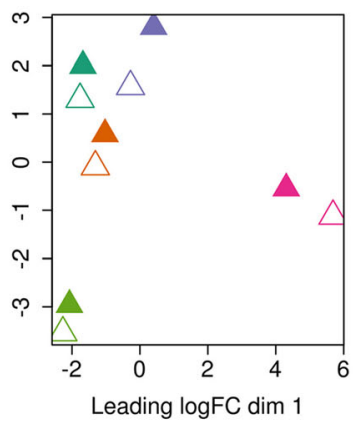

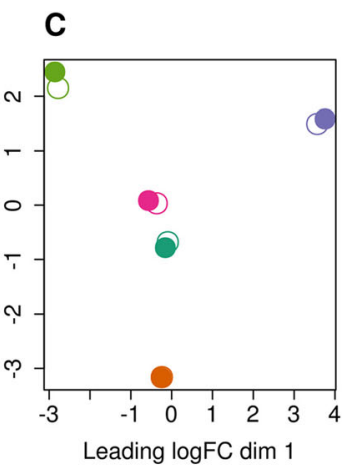

Fig. 2 Multidimensional scaling identifies significant contributions of individual variation to gene expression differences in shell repair in Mytilus edulis. MDS plots of expression counts for the filtered set of putative genes in (A) All libraries: Central mantle - left/damaged valve; Central mantle - right undamaged (control) valve: Mantle edge - left/damaged valve; Mantle edge - right undamaged (control) valve, B Central mantle libraries only (C) Mantle edge libraries only

haemocyte EST dataset were extracted from MytiBase [32] and compared with the current dataset. Only one sequence with one of the SMP-associated domains (C1Q) was identified in both datasets. Thus evidence for haemocyte involved in damage repair is limited in $M$. edulis. Interestingly, transcripts highly expressed in the central mantle of the damaged valve during shell repair were also present in the mantle edge transcriptomes and with similar expression levels, suggesting a general similarity in function (Fig. 5).

\section{Discussion}

Biomineralization is a complex process, and subject to developmental and environmental control. Using a carefully internally-controlled gene expression analysis, this study identified a large number of putative genes that may be involved in coordinating and carrying out shell repair in M. edulis, an important ecosystem and aquaculture species. Importantly the experimental design controlled for the known high genetic variation in $M$. edulis $[2,26,27]$ by exploiting the bivalve condition and using a matched pair analysis, whereby the control and treated (damaged) samples were taken from the same individual (Fig. 1) [20]. The sampling regime minimised individual effects (both genetic and environmental) on signal discovery, as confirmed by the MDS plots, in which the variability between individuals was much larger than the difference between experimental and

Table 2 Number of differentially expressed contigs between mantle tissue sections and annotation levels

\begin{tabular}{|c|c|c|c|c|c|}
\hline \multirow[t]{2}{*}{ Comparison } & \multicolumn{2}{|l|}{ Differential expression } & \multicolumn{3}{|c|}{ Annotation $^{\mathbf{b}}$} \\
\hline & $\begin{array}{l}\text { Tissue in which genes are more highly } \\
\text { expressed }\end{array}$ & $\begin{array}{l}\text { FDR }^{\mathrm{a}}<= \\
0.001\end{array}$ & SwissProt & Trembl & $\begin{array}{l}\text { SMP } \\
\text { database }\end{array}$ \\
\hline \multirow{2}{*}{$\begin{array}{l}\text { Undamaged valve: mantle edge vs. central } \\
\text { mantle }\end{array}$} & Mantle edge & 8,955 & 2,293 & 4,001 & 220 \\
\hline & Central mantle & 7,221 & 3,128 & 3,780 & 23 \\
\hline \multirow{2}{*}{$\begin{array}{l}\text { Damaged valve: mantle edge vs. central } \\
\text { mantle }\end{array}$} & Mantle edge & 7,340 & 2,039 & 3,484 & 155 \\
\hline & Central mantle & 6,229 & 2,614 & 3,144 & 28 \\
\hline \multirow{2}{*}{$\begin{array}{l}\text { Central mantle: Damaged vs. undamaged } \\
\text { valve }\end{array}$} & Damaged valve & 653 & 131 & 236 & 54 \\
\hline & Undamaged valve & 0 & 0 & 0 & 0 \\
\hline \multirow[t]{2}{*}{ Mantle edge: Damaged vs. undamaged valve } & Damaged valve & 0 & 0 & 0 & 0 \\
\hline & Undamaged valve & 0 & 0 & 0 & 0 \\
\hline
\end{tabular}

${ }^{a} F D R$ False Discovery Rate

${ }^{b}$ number of putative genes with annotation derived through sequence similarity searches of the stated databases 

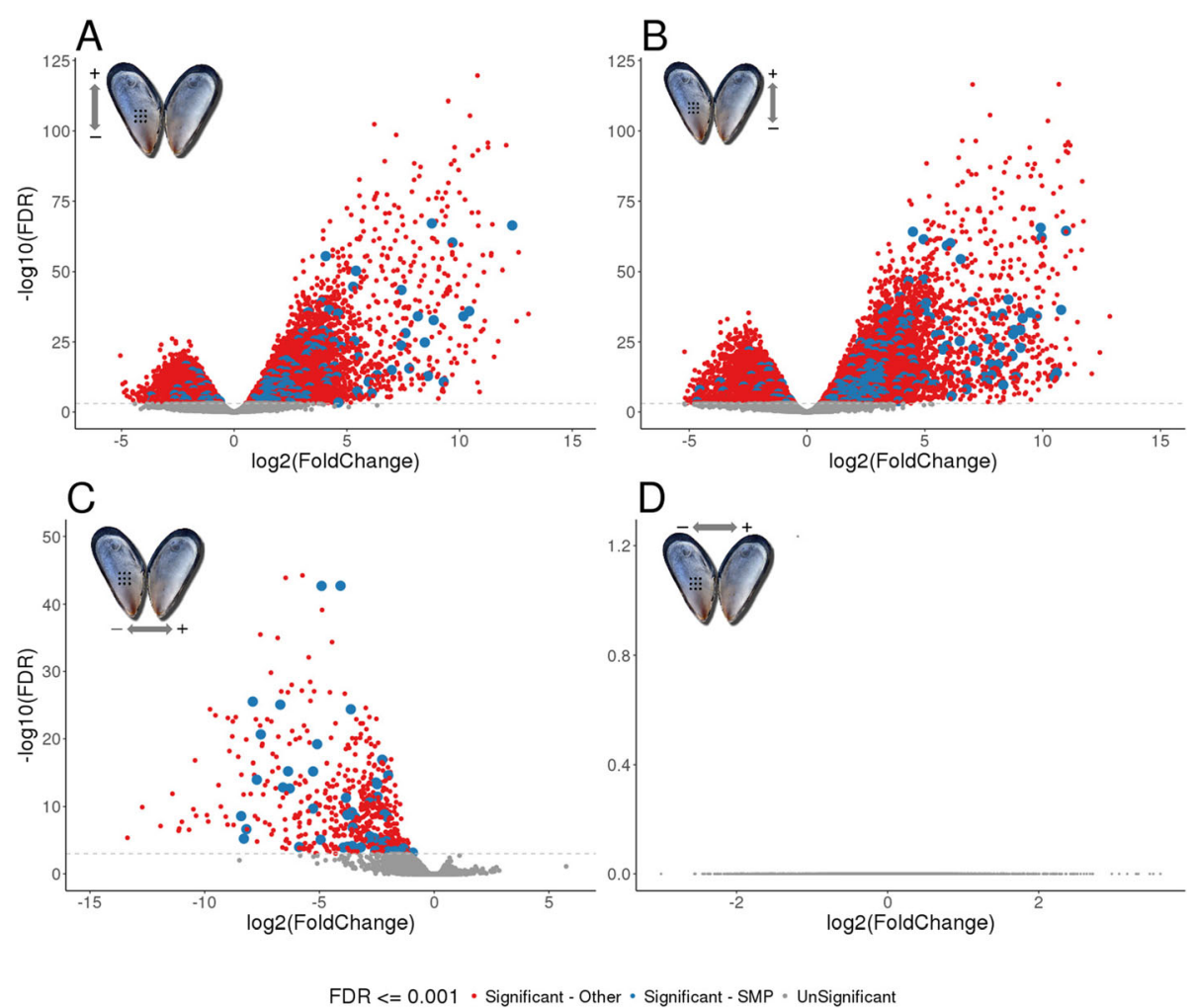

Fig. 3 Differential gene expression in Mytilus edulis mantle tissues during shell repair. Volcano plots detailing differential gene expression between the four mantle tissue libraries. Inset mussel pictures show comparisons detailed in each plot. A Damaged valve: mantle edge versus central mantle, B Control valve: mantle edge versus central mantle, C Damaged central mantle versus control central mantle, D Damaged mantle edge versus damaged central mantle. Dashed lines indicate the FDR value of 0.001 . Note: The axis scales are not the same across all plots

control groups (Fig. 2A-C) [2]. To optimise the detection of genes of interest, a modified damage-repair protocol was employed [6, 17-22]. A series of holes were drilled in the central region of the M. edulis shell to induce repair processes. Morphological assessment showed that by day 29 the central mantle had produced effective repair of the shell, including the deposition of calcite [20]. Normally it is the mantle edge tissue that is integral to active shell growth and the secretion and deposition of calcium carbonate. In contrast, in normal conditions the

Table 3 Enriched Molecular Function GO terms in differentially expressed genes in damaged and undamaged valves

\begin{tabular}{ll}
\hline Undamaged mantle edge & Damaged left valve \\
G-protein coupled receptor activity & $\begin{array}{l}\text { Peptidase inhibitor activity } \\
\text { Calcium ion binding }\end{array}$ \\
$\begin{array}{l}\text { Crotein binding } \\
\text { Sequence-specific DNA binding } \\
\text { lon channel activity }\end{array}$ & $\begin{array}{l}\text { Serine-type endopeptidase inhibitor } \\
\text { Metalloendopeptidase inhibitor }\end{array}$ \\
Undamaged central mantle & Undamaged right valve \\
Nucleic acid binding & None \\
Nucleotide binding & \\
ATP binding & \\
Metal ion binding & \\
\hline
\end{tabular}

role of the central mantle is to maintain the shell (as shown by the differences in expression profiles in Fig. 5 between undamaged and damaged mantle tissue). The two areas of mantle tissue also have very different anatomies, with the central mantle being a thin layer of epithelial tissue encompassing the animal and the mantle edge comprising a more complex folded structure, typically comprising three folds and periostracum in most bivalves [33, 34]. The large differences in the numbers of differentially expressed genes between the mantle edge and the central mantle (Table 2; Fig. 3) and associated GO enrichments (Table 3) highlighted their distinct physiological roles. However, the mantle is a multifunctional organ and it is unlikely to be possible to identify biomineralization-specific genes solely on differential expression between the mantle edge and central mantle. Previous studies have examined mantle edge responses to damage and modulation during growth, and thus risk confounding normal growth and repair.

The current experimental design was based on the hypothesis that inducing shell repair in the central mantle would specifically invoke expression of genes normally expressed by the mantle edge associated with shell production. By assessing the response of central mantle 


\begin{tabular}{|c|c|c|c|c|c|}
\hline & 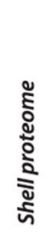 & 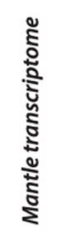 & 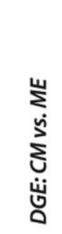 & 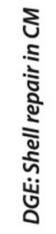 & 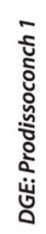 \\
\hline Alpha CA (Nacrein) & $\square$ & $\square$ & & UP & $\square$ \\
\hline Alveoline-like & $\square$ & $\square$ & & & \\
\hline Amine oxidase & & $\square$ & ME & UP & $\square$ \\
\hline Apextrin & & $\square$ & ME & & \\
\hline Basic protein N23 & & $\square$ & ME & & \\
\hline B-hexosaminodase & & $\square$ & & UP & $\square$ \\
\hline B-Imase (Gigasin6) & & $\mathbf{\square}$ & ME & UP & $\square$ \\
\hline BPTI/Kunitz & $\square$ & $\square$ & ME & UP & $\square$ \\
\hline B-Thymosin & $\square$ & $\square$ & & & $\square$ \\
\hline C-Lectin (Perlucin) & $\square$ & $\square$ & & UP & $\square$ \\
\hline $\mathrm{C} 1 \mathrm{Q}$ & $\square$ & $\square$ & & UP & $\square$ \\
\hline Chitin binding (VWA) & $\square$ & $\square$ & ME & $P$ & $\square$ \\
\hline Concanavalin-A & $\square$ & $\square$ & ME & UP & $\square$ \\
\hline Cyclophilin PPlase & & $\square$ & & & $\square$ \\
\hline Dermatopontin & & $\square$ & & & \\
\hline Dopamine B-h-ase & & $\square$ & ME & UP & $\square$ \\
\hline EF-Hand & & & & $P$ & \\
\hline EGF-like & & $\square$ & ME & UP & \\
\hline Ependymin & & $\square$ & & & \\
\hline FAD/NAD & $\square$ & $\square$ & ME & UP & \\
\hline FAMeT & & & & $P$ & \\
\hline Fibronectin III (IG) & $\square$ & $\square$ & & UP & $\square$ \\
\hline Filament/Filamin & $\square$ & $\square$ & ME & & $\square$ \\
\hline Fructose-BiP-ose & $\square$ & $\square$ & & & \\
\hline GFR (Perlustrin) & & & & & \\
\hline Gigasin $1,4,5$ & & & & & \\
\hline Gigasin 3a & & $\square$ & ME & UP & $\square$ \\
\hline Gly-Hyd (Chitinase) & $\square$ & $\square$ & & UP & 口 \\
\hline Haem peroxidase & & $\square$ & ME & UP & $\square$ \\
\hline Kazal domain & & $\square$ & ME & $\mathrm{P}$ & $\square$ \\
\hline Liprin/alpha motif & & $\square$ & & & \\
\hline Lysozyme/Gly-Hyd & & $\square$ & ME & & \\
\hline Chitin-S (Myn/P-loop) & & $\square$ & ME & UP & $\square$ \\
\hline Mytilin & $\square$ & $\square$ & ME & UP & \\
\hline Peptidase C1A & $\square$ & $\square$ & & UP & $\square$ \\
\hline Peroxiredoxin & & $\square$ & $\mathrm{CM}$ & & $\square$ \\
\hline RLCD & $\square$ & $\square$ & ME & UP & $\square$ \\
\hline SCP-domain & & $\square$ & ME & UP & $\square$ \\
\hline Sushi/Chitin-bind & & $\square$ & & & $\square$ \\
\hline TIMP & & $\mathbf{\square}$ & & $P$ & \\
\hline Transgelin-Calponin & $\square$ & $\mathbf{\square}$ & ME & & $\square$ \\
\hline Tyrosinase & & $\square$ & ME & UP & $\square$ \\
\hline IMSP. (Ruditapes) & & $\square$ & & & \\
\hline VWA (PIF, Collagen) & $\square$ & $\square$ & ME & $\mathrm{P}$ & \\
\hline WAP (Perwaplin) & $\square$ & $\square$ & & UP & \\
\hline
\end{tabular}

Fig. 4 Shell matrix protein homologues identified in Mytilus edulis shell proteomes, transcriptomes, and differential gene expression. For each identified protein or protein domain the columns indicate: Shell proteome: Previously identified shell proteome sequences; Mantle transcriptome: Transcripts previously identified in mantle transcriptome studies; DGE: CM vs. ME: Differential gene expression (DGE) identified in the central mantle (CM) versus the mantle edge (ME); DGE: shell repair in CM: Trajectory of DGE in the central mantle (UP = up-regulation; $P=$ putative shell proteins with no strong sequence similarity to, but with similar functional domains to known SMPs); DGE: Prodissoconch I: Genes differentially expressed in the prodissoconch I in transcriptomic analysis of development. The haemocyte dataset has not been included, as only one domain (C1Q) in common was identified

tissue to damage, switching from a low level of maintenance to active repair and reconstruction, it was possible to identify signals specific to the biomineralization process. Similarly, as wounding may induce wholeorganism stress and immune processes, the undamaged valve was used as a within-individual control to remove systemic gene expression responses (Fig. 5) [2]. All sampled $M$. edulis were healthy and active at the time of sampling, suggesting that the experimental damage had not resulted in major systemic infection or necrosis. Multidimensional scaling analysis identified interindividual variation as a major component describing expression level variation, and inter-individual variation was much larger than the difference between experimental and control valves (Fig. 2A-C) [2]. This approach should also be effective in analysis of other traits in this and other species of bivalve.

In mollusc damage-repair experiments, the level of response in the mantle tissue can depend heavily on where the damage was caused relative to where the mantle tissue was sampled [22]. In the current experiment gene expression of the mantle edge in the damaged valve was not affected during repair (Fig. 3D) suggesting that at this late stage of the repair process, gene expression effects were localized to tissue at the area of damage. This does not mean that mantle edge tissue did not respond to damage or was not involved in repair, but that the repair occurring in the this region of the mantle did not result in changes in gene expression over the normal biomineralization programmes active in this tissue. Many genes that were highly expressed in the central mantle of the damaged valve during shell repair also had high expression in the mantle edge (Fig. 5). Thus, the functions of the central mantle can transition to resemble those of the mantle edge during shell healing, in keeping with observations of altered mantle tissue ultrastructure during shell repair in bivalves [35, 36]. As thickening and repair of central shell parts occur in adult $M$. edulis, for example in response to high predator densities, shell boring polychaetes such as Polydora 


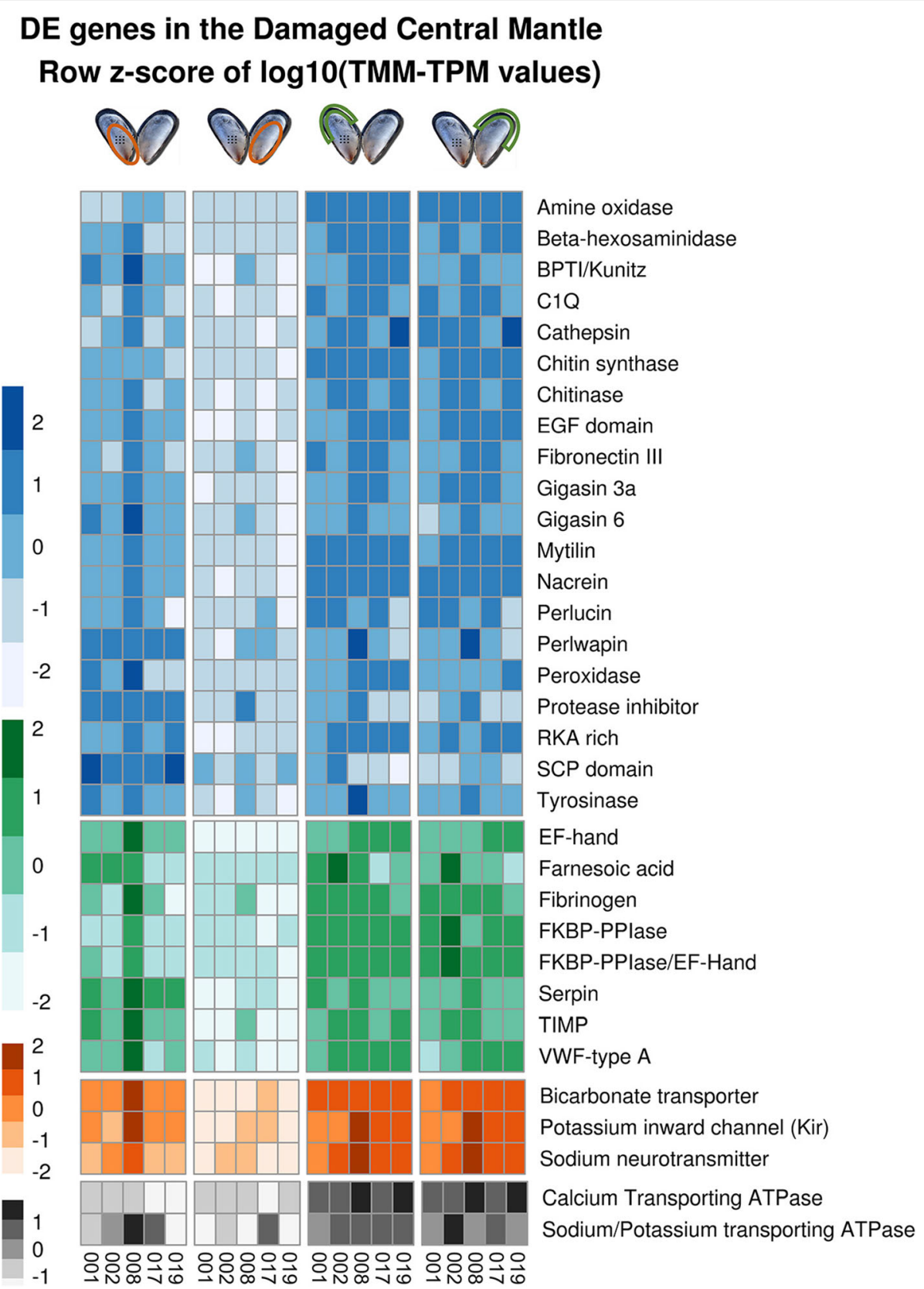

Fig. 5 Expression of selected sets of differentially expressed genes in central mantle during shell repair in Mytilus edulis. For each differentially expressed gene set (rows) four sets of five columns show the fold expression change in each of the five individuals (001-005). The sets of columns from left to right are: Damaged central mantle, Control central mantle, Damaged mantle edge, and Control mantle edge. The differentially expressed gene sets are grouped and colour coded: Blue: DE genes with sequence similarity to SMPs, ordered by SMP name; Green: DE genes with domains found in SMPs, but no sequence similarity to known SMPs, ordered by domain name; Orange: DE genes containing transmembrane domains; Grey: Non-DE genes with sequence similarity to ATPases of interest

species, or in response to specific local habitat conditions [37-39], this phenotypic plasticity is of adaptive significance.

The hypothesis of critical involvement of haemocytes in repair-associated biomineralization [11-14] was not supported in $M$. edulis. Cross comparison of the genes highly expressed in the central mantle during shell repair with an EST dataset generated from Mytilus haemocytes identified very few shared genes, highlighting their different functional repertoires. Molluscs have an open circulatory system, where the haemocytes are not confined to the haemolymph and are free to move into surrounding tissues and mantle cavity [40]. At a general functional level, only three domains $(\mathrm{C} 1 \mathrm{Q}$, tumour necrosis 
factor-like (TNF) and FN3) were found in proteins expressed in both haemocytes and adult mollusc SMPs. These domains are associated with proteins involved in the mollusc, and other non-vertebrate, immune responses [41-43]. Genes encoding these domains were highly expressed in the mantle edge compared to the central mantle in the control valve, suggesting a higher level of haemocyte activity in the mantle edge compared to the central mantle (Fig. 4). This is consistent with the positions of these tissues in the animal and their different functions. The mantle edge faces the external environment and therefore would be expected to require increased levels of immune defence compared with internal tissues. The identification of immune-related domains within shell proteomes has led to the suggestion that shells are not only structurally protective, but may also play a role in biochemical defence [44].

Previous analyses of diverse mollusc gene sets has shown that some genes involved in biomineralization can be highly divergent between species [45], and genes involved in shell production can be members of lineagerestricted protein families or unique adaptations of conserved genes through the acquisition of new domains and domain shuffling [46]. In this study a dataset of experimentally determined SMPs, and the protein functional domains within those proteins was produced and is openly available at https://doi.org/10/cz2w. Screening the $M$. edulis mantle transcriptomes for sequences homologous to these genes or containing these domains provided a primary list of several hundred candidate SMPs, and this candidate set was further refined through differential expression analysis. In the 653 putative genes ( $2 \%$ of all putative genes) whose expression was specifically modulated following to damage to the shell, half (325) had significant similarity to previously determined protein sequences, including SMPs. Among the 328 putative genes that had no significant similarity to other proteins, an additional $10 \%$ were detected with similarity to protein domains previously associated with shell formation. Many of these unknowns encoded predicted proteins with secretory leader peptides (39 sequences), coiled domains (16 sequences) and natively disordered regions (91 sequences, $14 \%$ of all differentially expressed genes). Natively disordered regions are characteristic of repetitive low complexity domain proteins (RLCDs), which are often present in shell proteomes and transcriptomes in high numbers as a result of species-specific expansions [47-49]. The identification of 91 such domains in this dataset (almost 14\% of damage-repair differentially expressed sequences) indicated that similar expansions of RLCD families have also occurred in Mytilus.

Many of the repair-upregulated genes had functional annotations previously indicated as important in biomineralization, but this study identified further annotations that extend this model. Many repair-upregulated genes had annotations associated with carbohydrate-binding: C-type lectin, beta-hexosaminidase, glycosyl hydrolase, chitinase and chitin-binding. Of particular interest was the identification of chitin-binding, which was also one of the GO terms enriched in the central mantle during repair (Table 3). Support for a role of chitin in the shell comes from experiments examining the effects of chitinase inhibitors on adults and larvae of the freshwater gastropod, Lymnaea stagnalis and the mussel Mytilus galloprovincialis. Treatment resulted in thinner shells and malformations [50, 51]. Chitin-binding domains are also found in the SMPs Pif97 and blue mussel shell protein (BMSP). These two proteins also have conserved von Willebrand factor A domain (vWA) domains [52], and vWA domains were found in several additional $M$. edulis repair-upregulated genes. Other protein-protein interaction domains found in SMPs such as epidermal growth factor (EGF), fibronectin type III (FN3) and whey acidic protein repeats (WAP) were also found in otherwise novel repair-upregulated genes (Fig. 4). VWF, along with FN3 is involved in cell adhesion and wound healing $[53,54]$. Epidermal growth factor (EGF) domains are found in gigasin-2 and other EGF-like proteins and is a common domain in secreted or membrane bound proteins [23, 55]. Tyrosinase proteins were also upregulated during repair. These proteins are critically involved in the formation of the periostracum, the initial organic layer integral to calcium carbonate deposition [56]. It was perhaps, not surprising to identify three domains (chitin-binding, vWA and tyrosinase) along with carbonic anhydrase (another domain expressed in this damage-repair study), in the up-regulated gene set. These are all members of a proposed universal molluscan biomineralization tool kit, a core set of protein domains shared between all bivalves irrespective of calcium carbonate polymorph and microstructure [44]. Other SMPs, highly expressed during shell repair included the SCP domain, first identified in Lottia and Gigasin 3a from Crassostrea [23, 57]. These two domains were also identified in the Mytilus prodissoconch I transcriptome [31].

GO analysis identified other processes active during M. edulis shell repair and deposition. Peptidase inhibitor activity, serine-type endopeptidase inhibition and metalloendopep tidase activity were enriched in the central mantle (Table 3) [58]. These GO terms are associated with known SMPs such as perlwapin, BPTI/kunitz, alpha-2-macroglobulin, kazal and WAPtype 'four-disulfide core' domains, tissue inhibitor of metalloproteinase (TIMP) and serine protease inhibitors (Serpins). Furthermore, these domains are all generally found in proteins with proteinase inhibitor activity. Proteases and protease inhibitors were shown 
to be directly involved in the nucleation and, or, growth and termination of crystal calcification, respectively. For example, serine proteases promote mineralization in vertebrates and bacteria, with serine protease inhibitors controlling this mineralization [59, 60]. In addition, metallopeptidases have been shown to assist in enamel calcification in humans [61] and perlwapin inhibits growth of nacre crystals [9].

Genes with potential enzymatic functions found to be upregulated during repair included several known biomineralization enzymes such as carbonic anhydrase and tyrosinase, but some repair-upregulated genes were annotated with functions not previously strongly associated with biomineralization (Fig. 4). The rediscovery of known biomineralization genes supported the assertion that the novel genes are very likely also biomineralisation toolkit loci. Genes predicted to encode proteins with a farnesoic acid O-methyltransferase (FaMeT) domain were upregulated in the repairing tissue. FaMeT catalyzes the formation of methyl farnesoate from farnesoic acid. Methyl farnesoate is an important hormone protein in crustaceans, with possible roles in moulting [62]. The FaMeT domain was previously identified in SMPs from the gastropod Haliotis [47] and these findings in a bivalve suggest that FaMeT involvement in biomineralisation process may be more widespread in molluscs. An amine oxidase (AO) was upregulated in the repairing tissue. AO was implicated in shell production during larval growth of the pearl oyster $P$. fucada [63] and this finding in M. edulis suggests that AO involvement in biomineralisation may be more general.

To orchestrate the expression of structural and enzymatic proteins for shell repair, the mollusc must modulate pathways of intra- and inter-cellular signalling and ion balance, but these will not necessarily be evident in SMP analyses. In this study, a number of genes were identified with annotations associated with intra- and inter-cellular signalling in the repair-upregulated set, including a rhodopsin-like G-protein coupled receptor (GPCR), frizzled-like domain and serine-threonine and tyrosine kinases. Whilst GPCRs have previously been identified in shell transcriptomes and have a known role in vertebrate calcium metabolism [64], specific involvement of rhodopsin-like GPCRs and frizzled domains have not previously been established in biomineralization experiments. Serine-threonine kinases are important in biomineralization of teeth and bones in vertebrates [65] and tyrosine kinases are important in phosphorylation of proteins secreted to the extracellular space [66]. Hence, there is the suggestion from vertebrate studies that their roles may be, at least partially, conserved in invertebrates.

Mantle tissue is responsible for calcium turnover and calcium deposition in the shell of molluscs [67] and this process requires active ion transport against environmental gradients and between cells. In the oyster $C$. gigas treatment of mantle tissue in vitro with the calcium channel inhibitor verapamil identified some of the entry into the outer mantle through L-type and T-type voltage-gated calcium channels located in the basolateral membrane $[68,69]$. However, as verapamil only reduced calcium transport by $20 \%$, other calcium transporting proteins are likely to be involved. Secretion of $\mathrm{Ca}^{2+}$ ions into the extrapallial space across the apical membrane was demonstrated via calcium ATPases and $\mathrm{Na}^{+} / \mathrm{Ca}^{2+}$ exchangers [68, 69]. Previous mantle transcriptome studies have shown that $\mathrm{Na}^{+} / \mathrm{K}^{+}$ATPase and bicarbonate transporters are upregulated during shell production $[29,58]$. In the experiment reported here, calcium transporting ATPases and sodium-potassium transporting ATPases were highly expressed in both repairing and control mantle edge tissue, but were not significantly overexpressed in repairing central mantle (Fig. 5). Solute carrier 4 bicarbonate transporters (SLC4 family members), sodium neurotransmitter symporters (SNSs) and inwardly rectifying potassium channels (Kirs) were identified in the repair-upregulated gene set. SNS belong to the solute carrier 6 gene family and are found in the plasma membrane of neuronal or neuroglial cells, where they are involved in the removal of neurotransmitters from the extracellular space, deriving energy for the uptake from the co-transport of $\mathrm{Na}^{+}$ions along the concentration gradient [70]. Kirs selectively mediate movement of $\mathrm{K}^{+}$ions from the extracellular space into the cell, against a $\mathrm{K}^{+}$gradient [71]. Kir channels are expressed in epithelial cells during osteoblastogenesis in humans [72], and in the freshwater ramshorn snail Planobarius corneus neuronal Kir channels maintain the resting potential of membrane in steady state and perturbation conditions [73]. Upregulation of expression of SNS and Kir loci suggests active neural involvement in repair, possibly maintaining membrane potential in the face of the considerable movement of charged ions required during shell repair.

\section{Conclusions}

Using a shell damage-repair model and a newly developed SMP and SMP-associated domain database, novel loci were identified with likely roles in biomineralization in the important bivalve $M$. edulis. A matched pair analysis to reduce the inherent high level of variability between individuals greatly facilitated the identification of genes that were differentially expressed during shell repair, identifying a large number of genes putatively involved in biomineralization, including several previously identified shell matrix proteins. Importantly this study extended the analysis of biomineralisation from the enzymatic and 
structural players in the shell matrix deposition process itself to loci likely to be involved in associated ion balance and signalling pathways. Our study provides new candidates for functional genomic and reverse-genetic analysis of mollusc biomineralization.

\section{Methods}

\section{Experimental design}

The shell damage-repair experiment is described in detail in a previous study [20] and comprised a total of 45 blue mussels (Mytilus edulis) sampled under different experimental conditions. In summary, M. edulis were acquired from the Kiel Fjord, Germany $\left(54^{\circ} 19.8^{\prime} \mathrm{N}, 10^{\circ} 9.0^{\prime} \mathrm{E}\right)$ between April 7-12 2011. Nine holes of 1mm in diameter were drilled (using drill N62/E, Proxxon, Germany) into the central area of the left valve while ensuring the animal soft tissue inside the shell was not harmed. The drilled mussels were suspended in Kiel Fjord in net cages (mesh diameter: $15 \mathrm{~mm}$ ) in $2 \mathrm{~m}$ depth, thus ensuring sufficient supply with planktonic food. Temperatures close to the cages rose from ca. $5-12{ }^{\circ} \mathrm{C}$ during the regeneration period (April - May 2011), pH (> 8.1-8.3), but salinity (13-16) fluctuated randomly (see Figure S1 in [20]). Mantle tissue was sampled 29 days after drilling. Mantle tissue from the edge and central areas of both valves was collected separately for RNA extraction and sequencing (Fig. 1A).

\section{RNA extraction and sequencing}

Total RNA from the mantle tissues $(n=5$ individuals, 4 tissue sections each: damaged valve mantle edge and central mantle and control valve mantle edge and central mantle) was extracted according to [74]. Complementary DNA (cDNA) was synthesized using the SMART cDNA synthesis kit (Clontech Laboratories, Mountain View, USA) with quality control performed using the Experion Automated Electrophoresis System (Bio-Rad,Hercules, USA) and the Nanodrop spectrophotometer (Thermo Scientific, Waltham, USA) for RNA as well as using the Bioanalyzer 2100 (Agilent Technologies, Santa Clara, USA) for cDNA. Non-stranded libraries were prepared using the TruSeq RNA Library Prep Kit (including polyA selection; Illumina, San Diego, USA). The indexed libraries from each sample were pooled at equimolar concentrations and sequenced on three HiSeq2000 lanes (Illumina, USA) following a $2 \times 125$ bp paired-end protocol at the University of Kiel Sequencing Facility at the Institute of Clinical Molecular Biology (IKMB) [26].

\section{Bioinformatics analysis}

All bioinformatic analyses were carried out using default software parameters unless otherwise specified. Adapters were trimmed from raw reads using Trimmomatic v.0.33 [75] and quality- and length-based trimming was performed using Fastq-mcf v.1.04.636 [76], setting the Phred quality score to 30 and minimum read length to $80 \mathrm{~b}$. Cleaned reads were normalized in silico with a coverage value of 30 (-max cov) and assembled using Trinity v.2.2.0 [77] with the max kmer cut-off value set to 2 . Non-normalized cleaned reads were then aligned to the de novo transcript assembly with Bowtie v.1.1.1 [78] and expression level estimation of putative genes was calculated using RSEM (RNA-Seq by Expectation-Maximization) v.1.2.20) [79]. Raw counts, and counts normalized using trimmed mean of maximum-values (TMM) and transcripts per million (TPM) were generated [80]. Differential gene expression analysis was performed using edgeR v.3.12.1 [81]. Raw counts were used for differential expression assessment, as edgeR performs its own sample normalization. Putative genes from the Trinity assembly that had fewer than 1 counts per million (CPM) read mapping values in at least 10 libraries were removed prior to analysis, as very low count values interfere with statistical approximations and exaggerate fold-change calculations [81]. Differential gene expression was assessed using an additive model to account for the paired experimental design (individual and tissue), and only results with an FDR of at least 0.001 were considered.

Contigs based on CPM-filtered putative genes were translated into putative protein sequences using Transdecoder in the Trinity pipeline. Translations shorter than 100 amino acids were discarded. The transcripts and protein sequences were annotated using multiple tools, including sequence similarity searches using BLAST (blastx or tblastx) v.2.2.30 [82] and domain searches using Interproscan v.5.25-64.0 [83]. BLAST searches were performed with an E-value cut off of less than 1e-10 against both protein (SwissProt, Trembl, our in-house SMP database (https://doi.org/10/cz2w)) and nucleotide (haemocyte expressed sequenced tags; [30], Mytilus larval transcriptome [29]) databases. BLAST matches postfiltered to excclude matches that covered less than $40 \%$ of the database entry. Domains and motifs were identified in the translated protein sequences and gene ontology $(\mathrm{GO})$ terms assigned using Interproscan and Interpro [83, 84]. Enrichment of GO terms was assessed using the Trinity Trinotate and GOSeq, with a FDR value of 0.001. TMM normalized TPM count values were used to generate heatmaps.

\section{Shell Matrix Proteins database}

An in-house molluscan Shell Matrix Proteins (SMP) database was developed to aid annotation (https://doi. org/10/cz2w [2]). SMPs of multiple species were downloaded from Uniprot (http://www.uniprot.org/) using keywords related to molluscan biomineralization 
(molluscs, shell, bivalve, aragonite, calcite, prismatic, foliated, mantle, mantle edge, central mantle, pallial mantle). The SMP dataset was manually curated by reviewing the publication related to each protein entry, and only entries that were validated to be present in molluscan shell matrices were retained. Sequences that were initially selected because they were only mantlespecific were not included. The SMP database contains 327 SMPs from molluscan genera. Domains found in the proteins in the SMP database were annotated Interproscan v.5.25-64.0 [83]. SMP database entries were grouped by functional domain, to reconcile differing naming conventions in previous studies.

\section{Abbreviations}

AO: Amine oxidase; BMSP: Blue mussel shell protein; cDNA: Complementary DNA; CPM: Counts per million; EGF: Epidermal growth factor; EST: Expressed sequence tag; FDR: False discovery rate; FN3: Fibronectin type III domain; GO: Gene ontology; Kir: Inwardly rectifying potassium channel; MDS: Multidimensional scale; RLCD: Repetitive low complexity domain protein; SEM: Scanning electron microscopy; SMP: Shell matrix protein; SNS: Sodium neurotransmitter symporter; TMM: Trimmed mean of maximum-values; vWA: Von Willebrand factor A domain; WAP: Whey acidic protein
\end{abstract}

\section{Acknowledgements}

The authors would like to thank Jamie Oliver (BAS) for his help with producing the figures and Ulrike Panknin (GEOMAR) for help with tissue sampling and RNA extraction.

\section{Authors' contributions}

TY conducted all the bioinformatics analyses and data interpretation and wrote the first draft of the manuscript; FM, AH, KR and TY were involved in the design and implementation of the experiments. KR supplied the Mytilus larval datasets. MB, FM and MSC were involved in data interpretation. All authors were involved in writing of the manuscript. The author(s) read and approved the final manuscript.

\section{Funding}

This manuscript was funded by the European Union Seventh Framework Programme [FP7] ITN project 'CACHE: Calcium in a Changing Environment' (www.cache-itn.eu) under REA grant agreement 605051, which funded both TY and KR and the Kiel Excellence Cluster 'Future Ocean' project CP1346 (which paid for the sequencing part of this project). MSC was supported by UKRI-NERC core funding to the British Antarctic Survey.

\section{Availability of data and materials}

The sequence dataset supporting the conclusions of this article is available in NCBI SRA (Short Read Archive) (https://www.ncbi.nlm.nih.gov/sra) under accession number SRP108359. The SMP database is publicly available from the NERC Polar Data Centre repository (https://www.bas.ac.uk/data/uk-pdc/) GB/NERC/BAS/PDC/01132 with DOI: https://doi.org/10/cz2w.

\section{Declarations}

Ethics approval and consent to participate

No permissions were required to collect the $M$. edulis and ethics approval was not required for the experiments.

\section{Consent for publication}

Not applicable.

\section{Competing interests}

The authors declare that they have no competing interests.

\section{Author details}

Ashworth Laboratories, University of Edinburgh, Institute of Evolutionary Biology, Charlotte Auerbach Road, EH9 3FL Edinburgh, UK. ²British Antarctic Survey, Natural Environment Research Council, High Cross, Madingley Road, CB3 OET Cambridge, UK. ${ }^{3}$ GEOMAR Helmholtz Centre for Ocean Research, 24105 Kiel, Germany. ${ }^{4}$ Sanger Institute, Wellcome Genome Campus, Hinxton, Cambridgeshire, CB10 1SA Saffron Walden, UK.

Received: 20 October 2020 Accepted: 27 May 2021

Published online: 10 June 2021

\section{References}

1. Checa AG. Physical and biological determinants of the fabrication of molluscan shell microstructures. Front Mar Sci. 2018;5:353. https://doi.org/1 0.3389/fmars.2018.00353.

2. Yarra T: Transcriptional Profiling of Shell Calcification in Bivalves. PhD thesis, University of Edinburgh, UK, 2018.

3. Berland S, Marie A, Duplat D, Milet C, Sire JY, Bedouet L. Coupling proteomics and transcriptomics for the identification of novel and variant forms of mollusk shell proteins: A study with $P$. margaritifera. Chembiochem. 2011;12(6):950-61.

4. Suzuki M, Saruwatari K, Kogure T, Yamamoto Y, Nishimura T, Kato T, Nagasawa $H$. An acidic matrix protein, Pif, is a key macromolecule for nacre formation. Science. 2009:325(5946):1388-90.

5. Fang $D, X u G R$, Hu YL, Pan C, Xie LP, Zhang RQ. Identification of genes directly involved in shell formation and their functions in Pearl oyster, Pinctada fucata. PLoS ONE. 2011;6(7):e21860

6. Lin Y, Jia G, Xu G, Su J, Xie L, Hu X, Zhang R. Cloning and characterization of the shell matrix protein Shematrin in scallop Chlamys farreri. Acta Biochimica Et Biophysica Sinica. 2014;46(8):709-19.

7. Zhang C, Li S, Ma Z, Xie L, Zhang R. A novel matrix protein p10 from the nacre of pearl oyster (Pinctada fucata) and its effects on both $\mathrm{CaCO}_{3}$ crystal formation and mineralogenic cells. Mar Biotechnol. 2006;8(6):624-33.

8. Marin F, Amons R, Guichard N, Stigter M, Hecker A, Luquet G, Layrolle P, Alcaraz G, Riondet C, Westbroek P. Caspartin and calprismin, two proteins of the shell calcitic prisms of the Mediterranean fan mussel Pinna nobilis. J Biol Chem. 2005:280(40):33895-908.

9. Treccani L, Mann K, Heinemann F, Fritz M. Perlwapin, an abalone nacre protein with three four-disulfide core (whey acidic protein) domains, inhibits the growth of calcium carbonate crystals. Biophys J. 2006;91(7): 2601-8.

10. Mann K, Siedler F, Treccani L, Heinemann F, Fritz M. Perlinhibin, a cysteine-, histidine-, and arginine-rich miniprotein from abalone (Haliotis laevigata) nacre, inhibits in vitro calcium carbonate crystallization. Biophys J. 2007; 93(4):1246-54.

11. Mount AS, Wheeler AP, Paradkar RP, Snider D. Hemocyte-mediated shell mineralization in the eastern oyster. Science. 2004;304(5668):297-300.

12. Kadar E, Lobo-da-Cunha A, Azevedo C. Mantle-to-shell $\mathrm{CaCO}_{3}$ transfer during shell repair at different hydrostatic pressures in the deep-sea vent mussel Bathymodiolus azoricus (Bivalvia.Mytilidae). Marine Biol. 2009;156(5): 959-967.

13. Li SG, Liu YJ, Liu C, Huang JL, Zheng GL, Xie LP, Zhang RQ. Hemocytes participate in calcium carbonate crystal formation, transportation and shell regeneration in the pearl oyster Pinctada fucata. Fish Shellfish Immunol. 2016;51:263-70

14. Ivanina AV, Borah BM, Vogts A, Malik I, Wu JY, Chin AR, Almarza AJ, Kumta P, Piontkivska $\mathrm{H}$, Beniash $\mathrm{E}$, et al. Potential trade-offs between biomineralization and immunity revealed by shell properties and gene expression profiles of two closely related Crassostrea species. J Exp Biol. 2018;221(18):jeb183236.

15. Khalifa GM, Kahil K, Erez J, Ashiri IK, Shimoni E, Pinkas I, Addadi L, Weiner S. Characterization of unusual MgCa particles involved in the formation of foraminifera shells using a novel quantitative cryo SEM/EDS protocol. Acta Biomater. 2018;77:342-51.

16. Fleury C, Marin F, Marie B, Luquet G, Thomas J, Josse C, Serpentini A, Lebel $J M$. Shell repair process in the green ormer Haliotis tuberculata: A histological and microstructural study. Tissue Cell. 2008;40(3):207-18.

17. Takahashi J, Takagi M, Okihana Y, Takeo K, Ueda T, Touhata K, Maegawa S, Toyohara H. A novel silk-like shell matrix gene is expressed in the mantle edge of the Pacific oyster prior to shell regeneration. Gene. 2012;499(1):130-4. 
18. Wang XT, Li L, Zhu YB, Du YS, Song XR, Chen YX, Huang RL, Que HY, Fang $X D$, Zhang GF. Oyster Shell Proteins Originate from Multiple Organs and Their Probable Transport Pathway to the Shell Formation Front. PLoS One. 2013;8(6):e66522.

19. Pan C, Fang D, Xu GR, Liang J, Zhang GY, Wang HZ, Xie LP, Zhang RQ. A novel acidic matrix protein, PfN44, stabilizes magnesium calcite to inhibit the crystallization of aragonite. J Biol Chem. 2014;289(5):2776-87.

20. Hüning AK, Lange SM, Ramesh $\mathrm{K}$, Jacob DE, Jackson DJ, Panknin U, Gutowska MA, Philipp EER, Rosenstiel P, Lucassen M, et al. A shell regeneration assay to identify biomineralization candidate genes in mytilid mussels. Marine Genomics. 2016;27:57-67.

21. Sleight VA, Thorne MAS, Peck LS, Clark MS. Transcriptomic response to shell damage in the Antarctic clam, Laternula elliptica: Time scales and spatial localisation. Marine Genomics. 2015;20:45-55.

22. Sleight VA, Peck LS, Dyrynda EA, Smith VJ, Clark MS. Cellular stress responses to chronic heat shock and shell damage in temperate Mya truncata. Cell Stress Chaperones. 2018;23(5):1003-17.

23. Marie B, Le Roy N, Zanella-Cleon I, Becchi M, Marin F. Molecular evolution of mollusc shell proteins: Insights from proteomic analysis of the edible musse Mytilus. J Mol Evol. 2011;72(5-6):531-46.

24. Vendrami DLJ, De Noia M, Telesca L, Brodte EM, Hoffman J. Genome-wide insights into introgression and its consequences for genome-wide heterozygosity in the Mytilus species complex across Europe. Evol Appl. 2020;13(8):2130-42.

25. Stuckas H, Knöbel L, Schade H, Breusing C, Hindrichsen H-H, Bartel M, Langguth K, Melzner F. Combining hydrodynamic modelling with genetics: Can passive larval drift shape the genetic structure of Baltic Mytilus populations? Molecular Ecology. 2017; 26:2765-2782.

26. Murgarella M, Puiu D, Novoa B, Figueras A, Posada D, Canchaya C. A First Insight into the Genome of the Filter-Feeder Mussel Mytilus galloprovincialis. PLOS ONE. 2016;11(7):e0160081.

27. Li RH, Zhang WJ, Lu JK, Zhang ZY, Mu CK, Song WW, Migaud H, Wang CL, Bekaert M. The whole-genome sequencing and hybrid assembly of Mytilus coruscus. Front Genet. 2020;11:440.

28. Knobel L, Breusing C, Bayer T, Sharma V, Hiller M, Melzner F, Stuckas H. Comparative de novo assembly and annotation of mantle tissue transcriptomes from the Mytilus edulis species complex (M.edulis, $M$. galloprovincialis,M.trossulus). Marine Genomics. 2020;51:100700.

29. Herlitze I, Marie B, Marin F, Jackson DJ. Molecular modularity and asymmetry of the molluscan mantle revealed by a gene expression atlas. Gigascience. 2018;7(6):giy056.

30. Zhao R, Takeuchi T, Luo Y-J, Ishikawa A, Kobayashi T, Koyanagi R, VillarBriones A, Yamada L, Sawada H, Iwanaga S, et al. Dual gene repertoires for larval and adult shells reveal molecules essential for molluscan shell formation. Mol Biol Evol. 2018;35(11):2751-61.

31. Ramesh K, Yarra T, Clark MS, John U, Melzner F. Expression of calcificationrelated ion transporters during blue mussel larval development. Ecology Evolution. 2019;9(12):7157-72.

32. Venier P, De Pitta C, Bernante F, Varotto L, De Nardi B, Bovo G, Roch $P$, Novoa B, Figueras A, Pallavicini A, et al. MytiBase: a knowledgebase of mussel (M. galloprovincialis) transcribed sequences. BMC Genom. 2009;10:72.

33. Saleuddin ASM, Petit HP: The mode of formation and the structure of the periostracum. The Mollusca 1983;4:199-234. Pub Academic Press.

34. Harper EM. The molluscan periostracum: An important constraint in bivalve evolution. Palaeontology. 1997:40:71-97.

35. Beedham GE: Repair of the shell in species on Anodonta. Proceedings of the Zoological Society of London 1965;145:107-123.

36. Saleuddin ASM. The histochemistry of the mantle during the early stage of shell repair. The Journal of Molluscan Studies. 1967;37:371-80.

37. Ambariyanto, Seed R. The infestation of Mytilus-edulis linnaeus by Polydoraciliata (Johnston) in the Conwy estuary, North-Wales. J Molluscan Stud. 1991;57:413-24

38. Appleton RD, Palmer AR. Water-borne stimuli released by predatory crabs and damaged prey induce more predator-resistant shells in a marine gastropod. Proc Natl Acad Sci USA. 1988;85(12):4387-91.

39. Telesca L, Peck LS, Sanders T, Thyrring J, Sejr MK, Harper EM. Biomineralization plasticity and environmental heterogeneity predict geographical resilience patterns of foundation species to future change. Glob Change Biol. 2019;25(12):4179-93.

40. Gosling E. Bivalve Molluscs: Biology, Ecology and Culture. Pub. WileyBlackwell; 2003. 456p.
41. Gerdol M, Manfrin C, De Moro G, Figueras A, Novoa B, Venier P, Pallavicini A. The C1q domain containing proteins of the Mediterranean mussel Mytilus galloprovincialis: A widespread and diverse family of immune-related molecules. Dev Comp Immunol. 2011;35(6):635-43.

42. Hanington PC, Zhang SM. The primary role of fibrinogen-related proteins in invertebrates is defense, not coagulation. J Innate Immun. 2011;3(1):17-27.

43. Adema CM. Fibrinogen-related proteins (FREPs) in mollusks. Result Probl Cell Differ. 2015;57:111-29.

44. Arivalagan J, Yarra T, Marie B, Sleight VA, Duvernois-Berthet E, Clark MS, Marie A, Berland S. Insights from the shell proteome: Biomineralization to adaptation. Mol Biol Evol. 2017;34(1):66-77.

45. Jackson DJ, McDougall C, Green K, Simpson F, Woerheide G, Degnan BM. A rapidly evolving secretome builds and patterns a sea shell. BMC Biol. 2006;4:40.

46. Kocot KM, Aguilera F, McDougall C, Jackson DJ, Degnan BM. Sea shell diversity and rapidly evolving secretomes: insights into the evolution of biomineralization. Frontiers in Zoology. 2016;13:23.

47. Jackson DJ, McDougall C, Woodcroft B, Moase P, Rose RA, Kube M, Reinhardt R, Rokhsar DS, Montagnani C, Joubert C, et al. Parallel evolution of nacre building gene sets in molluscs. Mol Biol Evol. 2010;27(3):591-608.

48. McDougall C, Aguilera F, Degnan BM. Rapid evolution of pearl oyster shell matrix proteins with repetitive, low-complexity domains. Journal of the Royal Society Interface. 2013;10(82):20130041.

49. Aguilera F, McDougall C, Degnan BM. Co-option and de novo gene evolution underlie molluscan shell diversity. Mol Biol Evol. 2017;34(4):779-92.

50. Schönitzer $V$, Weiss $I M$. The structure of mollusc larval shells formed in the presence of the chitin synthase inhibitor Nikkomycin Z. BMC Struct Biol. 2007;7:71.

51. Yonezawa M, Sakuda S, Yoshimura E, Suzuki M. Molecular cloning and functional analysis of chitinases in the fresh water snail, Lymnaea stagnalis. J Struct Biol. 2016;196(2):107-18.

52. Suzuki M, Iwashima A, Tsutsui N, Ohira T, Kogure T, Nagasawa $H$. Identification and characterisation of a calcium carbonate-binding protein blue mussel shell protein (BMSP), from the nacreous layer. Chembiochem. 2011:12(16):2478-87.

53. Whittaker CA, Hynes RO. Distribution and evolution of von Willebrand/ integrin a domains: Widely dispersed adhesion and elsewhere. Mol Biol Cell. 2002;13(10):3369-87.

54. Carini A, Koudelka T, Tholey A, Appel E, Gorb SN, Melzner F, Ramesh K. Proteomic investigation of the blue mussel larval shell organic matrix. J Struct Biol. 2019:208(3):107385.

55. Stenflo J, Stenberg Y, Muranyi A. Calcium-binding EGF-like modules in coagulation proteinases: function of the calcium ion in module interactions. Biochimica Et Biophysica Acta-Protein Structure Molecular Enzymology. 2000;1477(1-2):51-63.

56. Zhang C, Xie LP, Huang J, Chen L, Zhang RQ. A novel putative tyrosinase involved in periostracum formation from the pearl oyster (Pinctada fucata). Biochem Biophys Res Commun. 2006:342(2):632-9.

57. Marie B, Joubert C, Tayale A, Zanella-Cleon I, Belliard C, Piquemal D, Cochennec-Laureau N, Marin F, Gueguen Y, Montagnani C: Different secretory repertoires control the biomineralization processes of prism and nacre deposition of the pearl oyster shell. Proc Natl Acad Sci USA. 2012; 109(51):20986-20991.

58. de Wit P, Durland E, Ventura A, Langdon CJ. Gene expression correlated with delay in shell formation in larval Pacific oysters (Crassostrea gigas) exposed to experimental ocean acidification provides insights into shell formation mechanisms. BMC Genom. 2018;19:160.

59. Tiaden AN, Bahrenberg G, Mirsaidi A, Glanz S, Blueher M, Richards PJ. Novel function of serine protease HTRA1 in inhibiting adipogenic differentiation of human mesenchymal stem cells via MAP kinase-mediated MMP upregulation. Stem Cells. 2016;34(6):1601-14.

60. Hershey DM, Ren X, Melnyk RA, Browne PJ, Ozyamak E, Jones SR, Chang MCY, Hurley JH, Komeili A. MamO Is a repurposed serine protease that promotes magnetite biomineralization through direct transition metal binding in magnetotactic bacteria. PLoS Biol. 2016;14(3):e1002402.

61. Prajapati S, Tao JH, Ruan QC, De Yoreo JJ, Moradian-Oldak J. Matrix metalloproteinase-20 mediates dental enamel biomineralization by preventing protein occlusion inside apatite crystals. Biomaterials. 2016;75:260-70.

62. Kuballa AV, Guyatt K, Dixon B, Thaggard H, Ashton AR, Paterson B, Merritt DJ, Elizur A. Isolation and expression analysis of multiple isoforms of putative farnesoic acid O-methyltransferase in several crustacean species. Gen Comp Endocrinol. 2007;150(1):48-58. 
63. Liu J, Yang D, Liu S, Li S, Xu G, Zheng G, Xie L, Zhang R. Microarray: a global analysis of biomineralization-related gene expression profiles during larval development in the pearl oyster, Pinctada fucata. BMC Genom. 2015;16:325.

64. Clark MS, Thorne MAS, Vieira FA, Cardoso JCR, Power DM, Peck LS. Insights into shell deposition in the Antarctic bivalve Laternula elliptica: gene discovery in the mantle transcriptome using 454 pyrosequencing. BMC Genom. 2010;11:362.

65. Tagliabracci VS, Engel JL, Wen JZ, Wiley SE, Worby CA, Kinch LN, Xiao JY, Grishin NV, Dixon JE. Secreted kinase phosphorylates extracellular proteins that regulate biomineralization. Science. 2012;336(6085):1150-3.

66. Bordoli MR, Yum J, Breitkopf SB, Thon JN, Italiano JE, Xiao J, Worby C, Wong SK, Lin G, Edenius $M$, et al. A secreted tyrosine kinase acts in the extracellular environment. Cell. 2014;158(5):1033-44.

67. Jodrey LH. Studies on shell formation. III. Measurement of calcium deposition in shell and calcium turnover in mantle tissue using the mantleshell preparation and $\mathrm{Ca}^{45}$. Biol Bull. 1953;104:398-407.

68. Sillanpää JK, Ramesh K, Melzner F, Sundh H, Sundell K. Calcium mobilisation following shell damage in the Pacific oyster, Crassostrea gigas. Marine Genomics. 2016;27:75-83.

69. Sillanpää JK, Sundh H, Sundell KS: Calcium transfer across the outer mantle epithelium in the Pacific oyster, Crassostrea gigas. Proc Royal Soc B-Biol Sci. 2018, 285: 20181676.

70. Attwell D, Bouvier M. Neurotransmitter transporters: Cloners quick on the uptake. Curr Biol. 1992;2(10):541-3.

71. Miller C. An overview of the potassium channel family. Genome biology. 2000;1(4):REVIEWS0004-4

72. Sacco S, Giuliano S, Sacconi S, Desnuelle C, Barhanin J, Amri E-z, Bendahhou $\mathrm{S}$. The inward rectifier potassium channel Kir2.1 is required for osteoblastogenesis. Hum Mol Genet. 2015;24(2):471-9.

73. Kachman AN, Samoilova MV, Snetkov VA. Single potassium channel of anomalous (inward) rectification in mollusk neurons. Neurophysiology. 1989; 21(1):26-31.

74. Philipp EER, Kraemer L, Melzner F, Poustka AJ, Thieme S, Findeisen U, Schreiber S, Rosenstiel P. Massively parallel RNA sequencing identifies a complex immune gene repertoire in the lophotrochozoan Mytilus edulis. PLOS ONE. 2012;7(3):e33091.

75. Bolger AM, Lohse M, Usadel B. Trimmomatic: a flexible trimmer for Illumina sequence data. Bioinformatics. 2014;30(15):2114-20.

76. Aronesty E: ea-utils: Command-line tools for processing biological sequencing data, 2011, https://github.com/ExpressionAnalysis/ea-utils.

77. Grabherr MG, Haas BJ, Yassour M, Levin JZ, Thompson DA, Amit I, Adiconis $X$, Fan L, Raychowdhury R, Zeng QD, et al. Full-length transcriptome assembly from RNA-Seq data without a reference genome. Nat Biotechnol. 2011;29(7):644-U130

78. Langmead B, Salzberg SL. Fast gapped-read alignment with Bowtie 2. Nat Methods. 2012;9(4):357-U354.

79. Li B, Dewey CN. RSEM: accurate transcript quantification from RNA-Seq data with or without a reference genome. BMC Bioinformatics. 2011;12:323.

80. Finotello F, Lavezzo E, Bianco L, Barzon L, Mazzon P, Fontana P, Toppo S, Di Camillo B. Reducing bias in RNA sequencing data: A novel approach to compute counts. BMC Bioinformatics. 2014;15:7.

81. Robinson MD, McCarthy DJ, Smyth GK. edgeR: A Bioconductor package for differential expression analysis of digital gene expression data. Bioinformatics. 2010;26(1):139-40.

82. Altschul SF, Madden TL, Schaffer AA, Zhang JH, Zhang Z, Miller W, Lipman DJ. Gapped BLAST and PSI-BLAST: A new generation of protein database search programs. Nucleic Acids Res. 1997;25(17):3389-402.

83. Jones $P$, Binns $D$, Chang HY, Fraser M, Li WZ, McAnulla C, McWilliam H, Maslen J, Mitchell A, Nuka G, et al. InterProScan 5: Genome-scale protein function classification. Bioinformatics. 2014;30(9):1236-40.

84. Finn RD, Attwood TK, Babbitt PC, Bateman A, Bork P, Bridge AJ, Chang HY, Dosztanyi Z, El-Gebali S, Fraser M, et al. InterPro in 2017-beyond protein family and domain annotations. Nucleic Acids Res. 2017;45(D1):D190-9.

\section{Publisher's Note}

Springer Nature remains neutral with regard to jurisdictional claims in published maps and institutional affiliations.

Ready to submit your research? Choose BMC and benefit from:

- fast, convenient online submission

- thorough peer review by experienced researchers in your field

- rapid publication on acceptance

- support for research data, including large and complex data types

- gold Open Access which fosters wider collaboration and increased citations

- maximum visibility for your research: over $100 \mathrm{M}$ website views per year

At BMC, research is always in progress.

Learn more biomedcentral.com/submissions 